DOI: https://doi.org/10.21009/JPEB.004.1.6

\title{
KEPUASAN KERJA, KOMITMEN ORGANISASI DAN KEINGINAN BERPINDAH: STUDI PADA KARYAWAN PAHALA EXPRESS JATIASIH BEKASI
}

\author{
Sandra Purbasari Hasbie \\ Pahala Express, Jatiasih, Bekasi \\ sandra_pur@feunj.ac.id \\ Roni Faslah \\ Fakultas Ekonomi, Universitas Negeri Jakarta \\ ronifaslah@feunj.ac.id \\ Darma Rika Swaramarinda \\ Fakultas Ekonomi, Universitas Negeri Jakarta \\ darmarika_s@unj.ac.id
}

\begin{abstract}
The study aims to determine whether there is the influence of job satisfaction and organizationcommitment towards turnover intention of employess on Pahala Express Jatiasih Bekasi. The study was conducted for 3 (three) months since Januari 2015 until April 2015. The research method is survey method with the correlational approach.. The sample is 119 people, 5\% of the population. The sampling technique with proportional random technique.
\end{abstract}

Keywords: Job satisfaction, organization commitment, turnover intention

\section{ABSTRAK}

Penelitian ini bertujuan untuk mengetahui apakah terdapat pengaruh kepuasan kerja dan komitmen organisasi terhadap niat berpindah karyawan di Pahala Express Jatiasih Bekasi.Penelitian dilakukan selama 3 (tiga) bulan sejak Januari 2015 sampai April 2015.Metode penelitiannya adalah metode survei dengan pendekatan korelasional. Sampelnya adalah 119 orang, 5\% dari populasi.Teknik pengambilan sampel dengan teknik random proporsional.

Kata Kunci: kepuasan kerja, komitmet organisasi, niat berpindah 


\section{PENDAHULUAN}

Sumberdaya

manusia merupakan faktor penentu yang sangat penting bagi keefektifan berjalannya sebuah kegiatan dalam suatu perusahaan. Keberhasilan dan kinerja sumberdaya manusia yang ada di dalam suatu bidang pekerjaan banyak ditentukan oleh tingkat kompetensi, profesionalisme, dan juga komitmennya terhadap bidang kerja yang ditekuninya itu. Oleh karena itu perusahaan perlu melakukan investasi dengan melaksanakan fungsi manajemen sumberdaya manusia yaitu mulai dari perekrutan karyawan, penyeleksian, pelatihan, pengembangan karir, penghargaan untuk karyawan yang berprestasi dan tetap mempertahankan sumberdaya manusia yang profesional dan berkompeten agar tidak kalah saing dengan perusahaan lainnya. Karena pada dasarnya sumberdaya manusia yang berkompeten, berkualitas dan profesional adalah investasi bagi perusahaan untuk dapat bertahan di dalam dunia bisnis yang ada.

Setiap perusahaan ingin karyawannya memiliki kemampuan produktivitas yang tinggi dalam bekerja.Ini merupakan keinginan yang ideal bagi perusahaan yang hanya berorientasi pada keuntungan semata.Saat ini yang terjadi adalah perusahaan tidak mampu membedakan mana karyawan yang produktif dan mana yang kurang produktif. Perusahaan lebih terfokus kepada pencapaian target produksi dan keinginan memimpin pasar. Akibatnya, sumberdaya manusia atau karyawan dianggap sebagai mesin atau alat produksi yang dapat digunakan kapan saja demi mencapai tujuan atau keuntungan perusahaan.

Perusahaan lupa akan kompetensi sumberdaya manusia yang ada di perusahaan yang harus selalu dikembangkan,diperlihara, dirawat dan diperlakukan dengan baik agar tetap dapat berproduksi dengan baik. Karena sumberdaya manusia yang ada di dalam sebuah perusahaan itu merupakan investasi dari sebuah perusahaan.

Selain itu ditambah pula dengan banyaknya jumlah tenaga kerja di Indonesia yang berlebih, menjadikan beberapa perusahaan tertentu merasa memiliki posisi tawar yang tinggi karena pasar tenaga kerja yang luas memungkinkan bagi perusahaan untuk mengganti keberadaan karyawan yang merasa tidak sesuai atau tidak sejalan dengan kepentingan perusahaan dengan karyawan yang sejalan dengan perusahaan.

Di saat perusahaan hanya terfokus pada keuntungan perusahaan dan di saat perusahaan harus memaksimalkan fungsi sumberdaya manusia yang ada. Maka pada saat ini pula akan banyak timbul reaksi negatif dari karyawan yang merasa kebutuhannya kurang diperhatikan, tidak adanya kepuasan kerja di dalam diri karyawan dan tidak mendapatkan hak yang seharusnya didapatkan, seperti pengembangan karir, penghargaan karyawan berprestasi atau berkompeten, pengabdian karyawan yang sudah lama bekerja, promosi jabatan dan lainnya. Reaksi 
negatif yang timbul dari karyawan tersebut biasanya terlihat dari absensi yang meningkat, mulai malas bekerja, naiknya keberanian untuk melanggar tata tertib perusahaan, sering mangkirnya karyawan saat jam kerja, hasil kerja karyawan yang mulai menurun, dan kinerja karyawan yang semakin rendah dan akan muncul niat dan keinginan karyawan untuk berpindah mencari alternatif pekerjaan lainyang akhirnyadapat berujung pada keputusan karyawan untuk meninggalkan pekerjaannya (turnover).

Saat ini tingginya tingkat intensi turnover menjadi masalah yaang serius bagi perusahaan, karena akan menimbulkan ketidakstabilan dan ketidakefektifan di perusahaan. Selain itu perusahaan juga akan mengalami frustasi ketika mengetahui proses rekrutmen yang telah berhasil menjaring karyawan yang berkompeten, berkualitas dan berpengalaman pada akhirnya menjadi sia-sia karena karyawan tersebut telah memilih pekerjaan yang lebih baik di perusahaan lain. Karena apabila intensi turnover disebuah perusahaan tinggi maka akan menimbulkan biaya tambahan untuk melakukan perekrutan, tes, wawancara dan pelatihan karyawan agar dapat menjadi karyawan yang profesional dan berkompeten. Demikian hal nya yang dialami dengan Pahala Express Jatiasih yang merupakan salah satu perusahaan yang bergerak di bidang jasa pengiriman barang express delivery courier dan cargo. Dalam lingkungan Pahala Express Jatiasih harapannya karyawan yang bekerja di Pahala Express Jatiasih ini dapat berkomitmen untuk tetap bersama-sama bekerja untuk mencapai tujuan perusahaan, namun pada kenyataannya intensi turnover di Pahala Express JatiAsih yang mengalami peningkatan setiap tahunnya.

\section{KAJIAN TEORITIK \\ Keinginan Berpindah \\ Pergantian karyawan atau} keluar masuknya karyawan dari perusahaan adalah suatu fenomena penting dalam kehidupan perusahaan. Namun ada kalanya pergantian karyawan memiliki dampak positif, untuk mengganti karyawan yang kurang potensial dengan karyawan yang lebih potensial dan berkualitas. Karena pada hakekatnya karyawan yang berkompeten, berkualitas dan profesional adalah investasi di dalam sebuah perusahaan. Namun sebagian besar pergantian karyawan membawa pengaruh yang dapat merugikan perusahaan, baik dari segi biaya maupun segi hilangnya waktu untuk melakukan tahap penyeleksian, pelatihan hingga dapat menghasilkan karyawan yang berkompeten dan profesional.

Definisi keinginan berpindah menurut Veithzal Rivai (2010), keinginan berpindah kerja adalah keinginan pekerja untuk berhenti dari organisasi karena pindah ke lain organisasi. Kemudian menurut Russ dan Mc Neily yang dikutip oleh Dwi Cahyono (2010) menyatakan bahwa turnover intention adalah pemikiran untuk keluar, keinginan untuk mencari lowongan pekerjaan di tempat lain, mengevaluasi ke- 
mungkinan untuk menemukan pekerjaan yang lebih baik di tempat lain.

Keinginan berpindah yang dialami oleh karyawan ini terdorong dari keinginan karyawan untuk mencari alternatif pekerjaan lain namun di bidang yang sama di perusahaan lain, yang dirasa perusahaan lain lebih mampu memberikan kepuasan kerja ataupun memberikan apa yang menjadi harapan dan tujuan mereka dibandingkan perusahaan sebelumnya.

\section{Kepuasan Kerja}

Dalam dunia kerja, kepuasan kerja merupakan hal yang sangat penting bagi setiap karyawan. Seorang karyawan yang merasa puas dengan pekerjaannya akan membawa dampak positif dalam pekerjaannya.Namun memang pada dasarnya kepuasan kerja merupakan hal yang bersifat individual karena setiap individu akan memiliki tingkat kepuasan yang berbeda-beda sesuai dengan apa yang ada di dalam dirinya dan sesuai dengan harapannya. Semakin banyak aspek pekerjaan yang sesuai dengan keinginan individu maka semakin tinggi pula kepuasan kerja yang di rasakan oleh karyawan.

Menurut Greenberg dan Baron (2003) kepuasan kerja sebagai sikap positif atau negatif yang dilakukan individual terhadap pekerjaan mereka. Husein Umar (2000) menyebut kepuasan kerja adalah seperangkat perasaan tentang menyenangkan atau tidaknya pekerjaan mereka.
Semakin sesuai apa yang telah dilakukan dengan keinginan individu, maka semakin tinggi pula kepuasan individu tersebut. Orang yang puas akan terlihat senang dalam melakukan pekerjaannya. Ini berarti seseorang yang memiliki tingkat kepuasan kerja yang tinggi akan cenderung memiliki perasaanperasaan yang positif terhadap pekerjaan yang mereka lakukan dan akan memiliki ikatan emosional yang lebihterhadap perusahaannya yang nantinya akan ditunjukkan melalui loyalitasnya sebagai karyawan. Selanjutnya menurut Handoko (2011) kepuasan kerja adalah keadaan emosional yang menyenangkan atau tidak menyenangkan dimana para karyawan memandang pekerjaan mereka.

Dari ketiga teori di atas dapat diartikan bahwa kepuasan kerja adalah suatu perasaan emosi positif (menyenangkan) atau negatif (tidak menyenangkan) dari seorang karyawan terhadap pekerjaannya. Seorang karyawan dengan tingkat kepuasan kerja yang tinggi akan menunjukan emosi yang positif (menyenangkan) terhadap pekerjaannya, namun apabila seorang karyawan tidak puas dalam pekerjaannya biasanya akan menunjukan emosi yang negatif (tidak menyenangkan) terhadap apa yang dikerjakannya.

Kepuasan kerja merupakan penilaian atau cerminan perasaan seseorang terhadap pekerjaannya. Seorang karyawan dengan tingkat kepuasan kerja yang tinggi akan menunjukan emosi yang positif (menyenangkan) terhadap peker- 
jaannya, namun apabila seorang karyawan tidak puas dalam pekerjaannya biasanya akan menunjukan emosi yang negatif (tidak menyenangkan) terhadap apa yang dikerjakannya.

Menurut Robbins (2006) kepuasan kerja adalah sikap umum terhadap pekerjaan seseorang, yangmenunjukkan perbedaan antara jumlah penghargaan yang diterima pekerjadan jumlah yang mereka yakini seharusnya mereka terima. Di dalam lingkungan sebuah perusahaan kerjasama antar karyawan harus selalu dibangun untuk mengoptimalkan pekerjaannya. Karena kerjasama rekan kerja dan kelompok kerja adalah sumber kepuasan kerja bagi karyawan secara individual. Sementara kelompok kerja dapat memberikan dukungan, nasehat dan bantuan kepada karyawan lainnya. Karena apabila terjalinnya kerja sama antar karyawan ini akan mempengaruhi intensitas interaksi dan keeratan dalam suatu kelompok.

\section{Komitmen Organisasi}

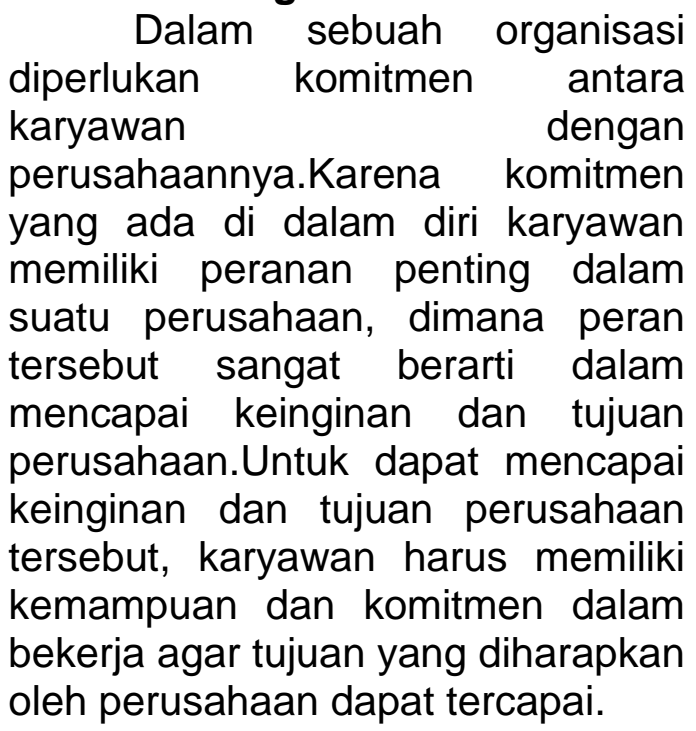

$\begin{array}{lrr}\text { Menurut Blau } & \text { dan Boal } \\ \text { (Sopiah, 2008) } & \begin{array}{r}\text { komitmen } \\ \text { sebagai }\end{array} \\ \text { organisasional } & \text { dan } & \text { loyalitas }\end{array}$
karyawan terhadap organisasi dan tujuan organisasi. O'Reilly (Sopiah, 2008) mendefinisikan bahwa: Komitmen karyawan pada organisasi sebagai ikatan kewajiban individu terhadap organisasi yang mencakup keterlibatan kerja, kesetiaan, dan perasaan percaya terhadap komitmen yang muncul bukan hanya bersifat loyalitas yang pasif, tetapi juga melibatkan hubungan yang aktif dengan organisasi kerja yang memiliki tujuan memberikan segala usaha demi keberhasilan organisasi yang bersangkutan.

Menurut Luthans (Kaswan, 2012), komitmen organisasi sering didefinisikan sebagai sikap yang merefleksikan loyalitas karyawan pada organisasi dan proses berkelanjutan dimana anggota organisasi mengekspresikan perhatian terhadap organisasi dan keberhasilan serta kemajuan yang berkelanjutan.

Dari beberapa teori yang dijabarkan di atas dapat diketahui bahwa bahwa komitmen organisasi yang ada di dalam diri karyawan bukan hanya sekedar menerima nilai-nilai dan tujuan-tujuan yang ada di dalam perusahaan, tetapi komitmen organisasi juga merupakan sikap dari seorang karyawan yang dapat mengidentifikasikan dirinya terhadap perusahaan dimana ia bekerja. Keterlibatan dan keberpihakan yang dilakukan oleh karyawan diperlihatkan dengan sikap loyalitas 
kontribusinya untuk selalu dapat memenuhi keinginan dan harapan perusahaan.

Komitmen organisasi dalam hal ini tidak hanya sekedar percaya dan menerima tujuan-tujuan organisasinya saja, melainkan komitmen organisasi yang ada di dalam diri karyawan ini harus adanya keterlibatan karyawan dan loyalitas karyawan. Karena karyawan yang berkomitmen terhadap perusahaannya ini biasanya akan berusaha sekuat tenaga agartetap bertahan dalam perusahaan dan akan selalu menunjukan kesetiannya kepada perusahaan di mana ia bekerja. Komitmen organisasi yang ada pada diri karyawan dapat muncul dalam bentuk yang berbeda-beda sesuai dengan apa yang karyawan tersebut rasakan terhadap perusahaan. Komitmen afektif (affective commitment) ini menunjukkan keterkaitan psikologis karyawan terhadapperusahaannya emosional untuk organisasi dan keyakinan dalam nilai- nilainya. Karyawan yang mempunyai komitmen afektif yang kuat akan tetap berada dalam perusahaan atas keyakinan dan keinginannya sendiri sehingga ia akan memiliki sikap yang positif terhadap pekerjaannya dan siap untuk memberikan usaha yang maksimal hingga tercapainya tujuan dari perusahaan.

Karyawan-karyawan dengan komitmen afektif yang kuat akan memilih untuk tetap bertahan berada di dalam perusahaan, karena mereka merasakan adanya kesamaan keyakinan pada nilai, visi maupun tujuan yang ingin dicapai oleh perusahaan, selain itu karyawan merasakan adanya $a$ sense of belonging to the organization, sudah adanya rasa ikut memiliki terhadap organisasi. Oleh karena itu, komponen komitmen afektif ini dianggap sebagai bentuk komitmen yang terbaik dari seorang karyawan terhadap perusahaan.

\section{METODOLOGI PENELITIAN}

Metode penelitianyang digunakan dalam penelitian ini adalah metode survei dengan mengetahui hubungan tiga variabel, yaitu variabel bebas dan variabel terikat.

Dalam penelitian ini yang menjadi variabel bebas (Variabel $\mathrm{X}_{1}$ ) kepuasan kerja dan (Variabel $X_{2}$ ) komitmen organisasi sebagai variabel yang mempengaruhi dan variabel terikatnya (Variabel Y) adalah keinginan berpindah (turnover intention)sebagai variabel yang dipengaruhi.

Penelitian ini dilaksanakan pada Pahala Express yang berlokasi di Jalan Jatiasih No. 289 Komsen, Jatiasih Bekasi.Pahala Express tersebut dipilih menjadi tempat objek penelitian karena menurut pengamatan peneliti bahwa keinginan berpindah (turnover intention) di Pahala Express Jati Asih dipengaruhi oleh kepuasan kerja dan komitmen organisasi.

Menurut Sugiyono(Sugiyono, 2013), "Populasi adalah wilayah generalisasi yang terdiri dari: objek atau subjek yang mempunyai kualitas dan karakteristik yang ditetapkan oleh peneliti untuk mempelajari dan kemudian hari ditarik kesimpulannya." 
Pada penelitian ini yang menjadi populasi adalah seluruh karyawan di Pahala Express. Populasi di perusahaan Pahala Express berjumlah 175 karyawan. Jumlah sampel diambil berdasarkan tabel Isaac dan Michael dalam buku Metode Penelitian Pendidikan, dengan taraf kesalahan $5 \%$ maka jumlah sampel penelitian ini sebanyak 119 karyawan.

Teknik pengambilan sampel menggunakan teknik acak proporsional (proportional random sampling). Artinya, "sampel diwakili sesuai dengan perbandingan (proporsi) frekuensinya di dalam populasi keseluruhan".

\section{HASIL DAN PEMBAHASAN}

Berdasarkan hasil penelitian regresi berganda yaitu $Y=96,468$ $0,313 X_{1}-0,460 X_{2}$. Dimana, nilai konstanta sebesar 96,468. Artinya jika tidak adanya kenaikan atau penurunan tingkat kepuasan kerja dan komitmen organisasi, maka keinginan berpindah nilainya adalah 96,468 .

Nilai koefisien $\left(b_{1}\right)$ sebesar -
0,313 artinya jika komitmen
organisasi nilainya tetap dan
kepuasan kerja mengalami
kenaikan 1 poin, maka keinginan berpindah akan menurun sebesar 0,313 dengan asumsi variabel independen lain nilainya tetap. Koefisien bernilai negatif artinya terdapat hubungan negatif antara kepuasan kerja dengan keinginan berpindah, semakin baik kepuasan kerja maka akan semakin menurun keinginan berpindah.

Nilai koefisien $\left(b_{2}\right)$ sebesar 0,460 artinya jika kepuasan kerja nilainya tetap dan komitmen organisasi mengalami kenaikan 1 poin, maka keinginan berpindah akan menurun sebesar 0,460 dengan asumsi variabel independen lain nialinya tetap. Koefisien bernilai negatif artinya terdapat hubungan negatif antara komitmen organisasi dan keinginan berpindah, semakin baik komitmen organisasi maka semakin menurun keinginan berpindah.

Pada penelitian ini, secara bersama-sama pengaruh kepuasan kerja dan komitmen organisasi terhadap keinginan berpindah (turnover intention) diperoleh koefisien determinasi dengan melihat $R^{2}$ sebesar 0,513 yang artinya kemampuan dari variabel kepuasan kerja dan komitmen organisasi untuk menjelaskan keinginan berpidahsecara stimulan yaitu $51,3 \%$ sedangkan sisanya $48,7 \%$ dipengaruhi oleh faktor lain yang tidak diteliti. Hasil dari uji hipotesis kedua variabel yaitu kepuasan kerja dan komitmen organisasi secara serentak memeiliki pengaruh terhadap keinginan berpindah pada karyawan Pahala Express Jatiasih.

Semakin tinggi kepuasan kerja dan komitmen organisasi yang dirasakan oleh karyawan, maka akan semakin rendah keinginan untuk berpindah pada karyawan. Demikian pula sebaliknya, Semakin rendah kepuasan kerja dan komitmen organisasi yang dirasakan oleh karyawan, maka akan semakin rendah keinginan untuk berpindah pada karyawan.

Kemudian dalam melakukan penelitian ini, peneliti menyadari 
bahwa penelitian ini tidak dapat sepenuhnya sampai pada tingkat yang kebenarannya mutlak, sehingga tidak menutup kemungkinan dilakukannya penelitian lanjutan.

\section{KESIMPULAN DAN SARAN}

Berdasarkan hasil penelitian tentang pengaruh kepuasan kerja dankomitmen organisasi

Hasil uji hipotesis menghasilkan

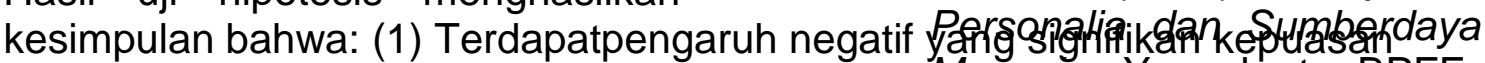
(Turnover Intention)akan rendah. Begitupula sebalikanya, jika kepuasan kerja dan komitmen organisasi rendah, maka keinginan berpindah (Turnover Intention)akan tinggi; (2) Terdapat pengaruh negatif yang signifikan antara kepuasan kerja dankeinginan berpindah (Turnover intention) dengan nilai thitung dari kepuasan kerja sebesar $(-4,283)<-t_{\text {tabel }}(-1,658)$. Artinya, jika kepuasan kerja tinggi maka k
(Turnover intention) dengan nilai thitung dari komitmen organisasi sebesar $t_{\text {hitung }}(-8,818)<-t_{\text {tabel }}(-$ $1,658)$ Artinya, jika komitmen organisasi tinggi maka keinginan berpindah (Turnover intention) rendah, dan sebaliknya jika komitmen organisasi rendah maka keinginan berpindah (Turnover intention) tinggi.

\section{DAFTAR PUSTAKA}

Baron, G. a. (2003). Behaviour Organization. Pearson Education International.
Cahyono, D. (2010). Pengaruh mentoring terhadap kepuasan kerja, konflik peran serta niatan untuk pindah (Studi empiris di Lingkungan Kantor Akuntan Publik). Jurnal SNA, Vol. 8, No. 15, September 2010. pengaruh kepuasan kerja dankomitm
Handoko, T. H. (2011). Manajemen Manusia. Yogyakarta: BPFEYogyakarta.

Kaswan. (2012). Manajemen Sumberdaya Manusia untuk Keunggulan Bersaing Organisasi. Yogyakarta: Graha IImu.

Rivai, V. (2010). Manajemen Sumberdaya Manusia Untuk Perusahaan. Jakarta: kerja dankomi

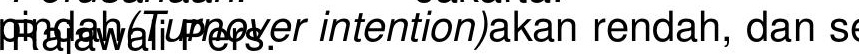

Robbins, S. P. (2006). Perilaku Organisasi. Jakarta: PT Indeks Kelompok Gramedia.

Sopiah. (2008). Perilaku Organisasi. Yogyakarta: Andi.

Sugiyono. (2013). Statistik Untuk Penelitian. Bandung: Alfabeta.

Umar, H. (2000). Bussines An Indroduction. Jakarta: Gramedia Pustaka Utama. 